\title{
An Odd Corner of the Province - Old Man on His Back Plateau
}

\author{
by John H. Hudson, Saskatoon
}

If one drives past Robsart on Highway 13 one may see a low range of hills on the southern horizon. The casual observer dismisses them as another of our numerous stretches of dry morainic hills. The naturalist, however, might observe that the west end seems to end abruptly in a sharp drop, which at the distance of Robsart appears as a nick in the southern horizon. This is abnormal for morainic hills and means some unusual land form. One learns nothing from maps, as there is no contour map of the area, and ordinary maps no more than name the hills "Old Man on his Back Plateau" without more data.

Becoming curious about the area, I drove down from the Cypress Hills to the west end of the plateau in late June, 1956. A reasonable sort of earth road brings one precisely (Fig. 1) to this west end 12.4 miles south from Robsart. The south side may be viewed by going south another three miles, then turning east on Highway 46 ; the plateau lies to the north all the way east to Divide.

At this west end the first thing that struck my eye was the steep rise (Fig. 2) up to the plateau top, a rise of $200-$ 300 feet above the road. This rise is covered with creeping juniper (Fig. 3 ), from which towards the top of the slope protrudes the odd cliff of yellowish sandstone. When I scrambled up to the top, a magnificent view was seen. Along the northern horizon the Cypress Hills were laid out in order from the West Block to Ravenscrag Butte. To the southeast a squarish tableland rose up to about eye level at no great distance-10 or 15 miles, I judged. (I later found this one to be Boundary Plateau). The unexpected sight was to the south. A range of jagged mountains rose about $1 \frac{1 / 2}{2}$ degrees above the horizon, and swept round in a $30^{\circ}$ arc from $8^{\circ}$ east of south to $20^{\circ}$ or $22^{\circ}$ west of south. By their degree of haziness I guessed them about thrice the distance of the Cypress Hills, which put them about sixty miles away. At that time I did not know their name or location; later I found out that these were the 7000 -foot altitude Bearpaw Mountains of Montana, and that my distance estimate was not too far off. It should be added that on later visits I found that the East Butte of the Sweetgrass Hills may be spotted on the southwestern horizon.

Returning from the skyline to the immediate neighbourhood, I saw that here at its west end the plateau top is almost flat, perhaps with a slight slope eastward. A few quartzite cobblestones and glacial erratics were lying about. Save for the erratics, glacial drift was almost lacking. The vegetation of the plateau was that of ordinary dry prairie, in spite of the altitude of over 3500 feet above sea level. No trees were to be seen, and the brush in gullies on north slopes was pretty stunted. This is dry country south of the Cypress Hills.

From the foot of the sharp drop the ground slopes gently away for a couple of miles or so till it reaches the general prairie level of about 3050 feet. This outer slope is rather sadlooking country, especially to the northwest. Seamed with shallow arroyos, and wanting in: sloughs, it abounds in clay-shale outcrops and burn-out pits, plain token of a shortage of glacial drift cover.

Later I did run across some published information on the plateau. A good description and early map were given by McConnell in 1885 (1), and some description and a good geological map by Furnival in 1946 (2). Their writings may be summed up thus: The plateau is roughly oval with the long axis running about 8 miles E.S.E. from its western tip in SE $1 / 4-10-3-25-W 3 r d$. Glacial drift is banked up against the north side and east end, blotting out its limits; the plateau merely fades away into rolling morainic hills. (These hills are responsible for the origin of the name, according to a yarn I have encountered somewhere but cannot place; their skyline as seen from the northwest is said to resemble the silhouette of a fat old man lying on his back with his knees drawn up.) Contrariwise, the almost driftless west 


\section{Views of Old Man On His Back Plateau}

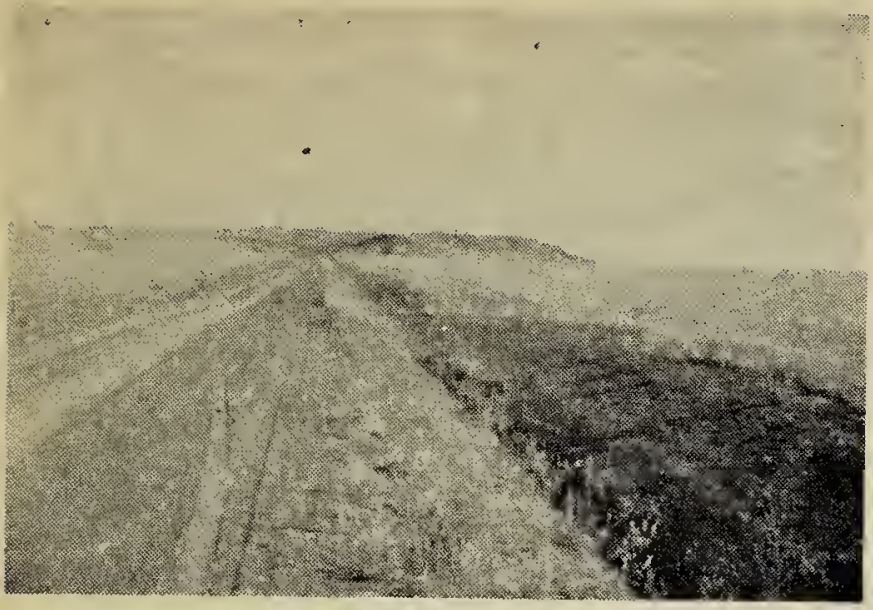

View of west end from the north; distance $11 / 2$ miles.

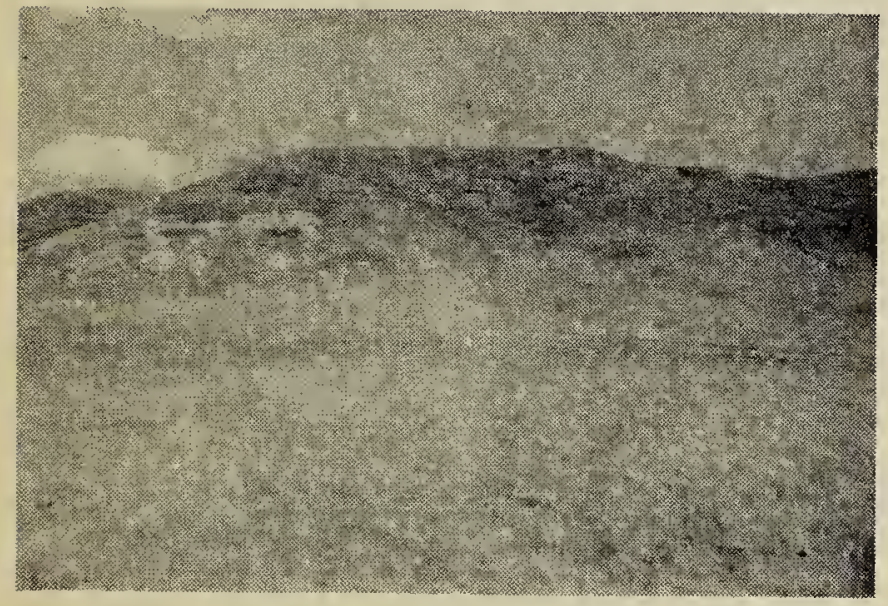

Close-up of west scarp; looking E.S.E. from 200 yards away. Shows juniper-covered sandstone slopes.

end and south side stand up as a steep-sided escarpment with good bedrock exposures. The hard cliffforming yellow sandstones (Fig. 4) of the Frenchman formation are the uppermost strata, about 60 feet thick. Below lie softer strata; a few feet of Whitemud white clayey sands, 18-70 feet of mostly arange sands of the Eastend formation, and then grey Bearpaw shales continuing on down slope to prairie level and deeper. One doesn't see much of the Bearpaw on the slopes due to a sandy junipercovered talus, but west of the road it outcrops on the gentle slope as light grey silts and clays. To the eastward along the south side of the escarpment, the glacial drift becomes thicker, outcrops fewer, and land forms more rounded.

As to the origin of the tableland, it is thought to be a remnant of an old land surface like the Cypress Hills, left as a hill by the removal of surrounding material. We may further surmise that it may have occu-

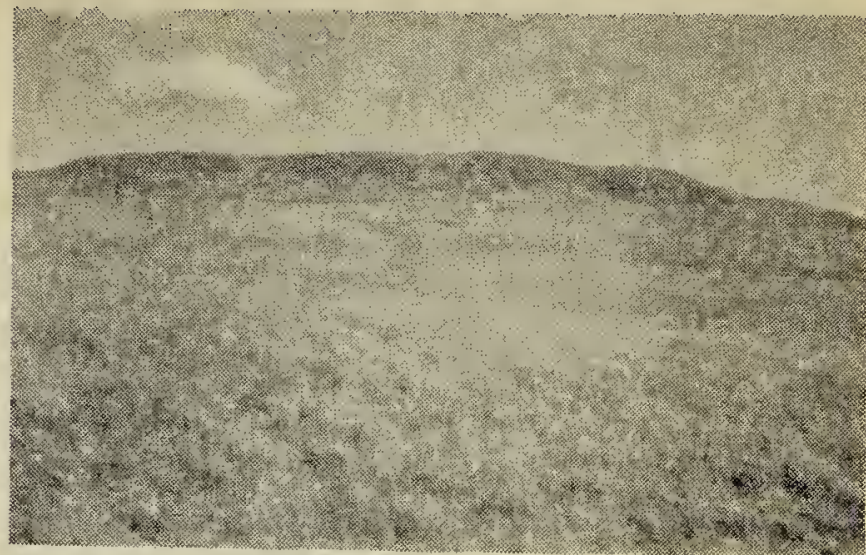

View of west end from the west; distance $1 / 2$ mile.

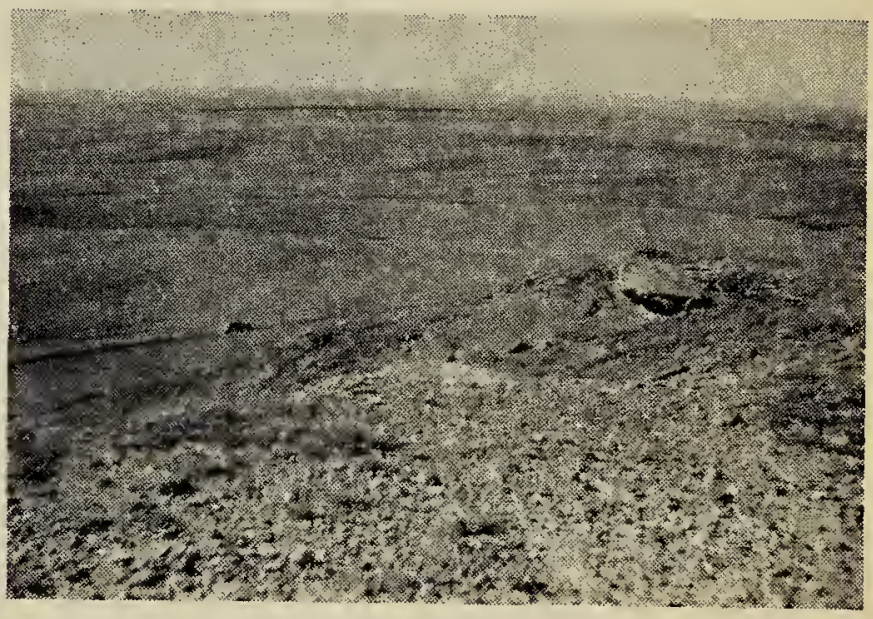

View from top looking north-west; shows sandstone ledge covering plateau with steep drop to barren plain beyond.

pied an interstream area in preglacial time-the areas furthest from the rivers are the last to be worn away. The hard sandstone of the topmost stratum tends to slow down erosional removal of the plateau. This old land surface may once have extended quite widely south of the Cypress Hills as a lower bench, of which Boundary Plateau and the bench along the north shore of Cypress Lake, along with our Old-Man-onhis-Back Plateau, may be remnants sundered by the slow erosion of rivers; at any rate they all rise to about the same elevation, 3500 feet.

\section{REFERENCES}

1. R. G. McConnell, 1885. Report on Cypress Hills, Wood Mountain, and adjacent country. Annual Reports of the Geological Survey of Canada, part $\mathrm{C}$.

2. G. M. Furnival, 1946. Cypress Lake Map Area. Geological Survey of Canada Memoir $\# 242$.

A few further comments may be found in $M$. Y. Williams and W. S. Dyer, 1930. Geology of Southern Alberta and Southwestern Saskatchewan. Geological Survey of Canada, Memoir \#163. 